\title{
PROMOSI KESEHATAN TENTANG CORONA VIRUS 2019 DI DESA DABOH KECAMATAN DELIMA KABUPATEN PIDIE
}

\section{HEALTH PROMOTION ABOUT CORONA VIRUS 2019 IN DABOH VILLAGE, DELIMA DISTRICT, PIDIE REGENCY}

\author{
$\operatorname{Kartika}^{1 *}$, Karmila ${ }^{2}$, Fakhryan Rakhman ${ }^{1}$ \\ ${ }^{1}$ Program Studi Keperawatan STIKes Medika Nurul Islam, Kota Sigli \\ ${ }^{2}$ Program Studi Keperawatan STIKes Medika Seramoe Barat, Kota Malaboh \\ *Email: dr.kartika85@gmail.com
}

(Diterima 28-08-2021; Disetujui 15-09-2021)

\begin{abstract}
ABSTRAK
Corona Virus 2019 merupakan jenis virus baru yang telah menyebar dengan luas ke berbagai wilayah dunia termasuk wilayah Indonesia. Salah satu cara yang dilakukan untuk menurunkan kasus ini adalah dengan mematuhi protokol kesehatan yang sudah diatur oleh negara dalam bentuk kebijakan, tetapi dalam prakteknya masaih banyak masyarakat yang tidak mematuhi kebijakan tersebut. Pengabdian masyarakat ini bertujuan untuk memberikan promosi kesehatan untuk mengedukasi mayarakat akan pentingnya mengikuti protokol kesehatan dalam mencegah penularan kasus covid-19. Kegiatan yang dilaksanakan berlangsung satu hari yaitu pada tanggal 01 Oktober 2020 mulai pukul 10.00-11.30 WIB di Meunasah Gampong Daboh. Metode yang dilakukan yaitu melakukan promosi kesehatan dengan metode ceramah yang dibantu dengan media laptop, powerpoint, LCD, dan alat pemancar suara. Peserta yang mengikuti kegiatan ini sebanyak 22 peserta karena diberlakukan jaga jarak dan semua peserta wajib melakukan prokes dengan menggunakan masker dan wajib cuci tangan di awal dan akhir pertemuan. Masyarakat yang hadir adalah para ibu rumah tangga Meunasah Gampong Daboh. Kesimpulan dalam kegiatan ini adalah adanya peningkatan pengetahuan dan sikap peserta tentang covid-19 sehingga masyarakat di masyarakat desa Meunasah Gampong meningkatkan kesadaran untuk berperilaku sesuai dengan protokol kesehatan. Diharapkan kepada peserta dapat berperan serta dalam menyebarluaskan informasi yang diperoleh dari kegiatan ini dan turut aktif dalam kebijakan pemerintah untuk menurunkan angka kesakitan covid-19.
\end{abstract}

Kata kunci : Corona Virus, Promosi Kesehatan, Pengetahuan, Sikap

\section{ABSTRACT}

Corona Virus 2019 is a new type of virus that has spread widely to various regions of the world including Indonesia. One way to reduce this case is to comply with the health protocols that have been regulated by the state in the form of policies, but in practice there are still many people who do not comply with these policies. This community service aims to provide health promotion to educate the public on the importance of following health protocols in preventing the transmission of COVID-19 cases. The activity was carried out for one day, namely on October 1, 2020 starting at 10.00-11.30 WIB at Meunasah Gampong Daboh. The method used is conducting health promotion with the lecture method assisted by laptop media, powerpoint, LCD and sound transmitters. There were 22 participants who took part in this activity because social distancing was enforced and all participants were required to carry out health procedures using masks and must wash their hands at the beginning and end of the meeting. The people who attended were housewives from Meunasah Gampong Daboh. The conclusion in this activity is that there is an increase in participants' knowledge and attitudes about covid-19 so that people in the Meunasah Gampong village community increase awareness to behave in accordance with health protocols. It is hoped that participants can participate in disseminating the information obtained from this activity and actively participate in government policies to reduce the number of COVID-19 illnesses.

Keywords: Corona Virus, Health Promotion, Knowledge, Attitude

\section{PENDAHULUAN}

Pada tanggal 31 Desember 2019, Tiongkok melaporkan kasus pneumonia misterius yang tidak diketahui penyebabnya. Dalam 3 hari, pasien dengan kasus tersebut berjumlah 
Promosi Kesehatan Tentang Corona Virus 2019 di Desa Daboh Kecamatan Delima Kabupaten Pidie Kartika, Karmila, Fakhryan Rakhman

44 pasien dan terus bertambah hingga saat ini berjumlah jutaan kasus. Pada awalnya data epidemiologi menunjukkan $66 \%$ pasien berkaitan atau terpajan dengan satu pasar seafood atau live market di Wuhan, Provinsi Hubei Tiongkok. Sampel isolat dari pasien diteliti dengan hasil menunjukkan adanya infeksi coronavirus, jenis betacoronavirus tipe baru, diberi nama 2019 novel Coronavirus (2019-nCoV). Infeksi virus Corona disebut COVID19 (Corona Virus Disease 2019) menular dengan sangat cepat dan telah menyebar ke hamper semua negara, termasuk Indonesia, hanya dalam waktu beberapa bulan. (Kemenkes, 2020).

Tanda dan gejala umum infeksi COVID-19 antara lain gejala gangguan pernapasan akut seperti demam, batuk dan sesak napas hingga pada kasus yang berat menyebabkan pneumonia, sindrom pernapasan akut, gagal ginjal dan bahkan kematian (DJASRI, 2020). Manifestasi klinisnya muncul dalam 2 hari hingga 14 hari setelah terjadi pajanan. Hingga saat ini masih diyakini bahwa transmisi penularan COVID-19 adalah melalui droplet dan kontak langsung, kecuali bila ada tindakan medis yang memicu terjadinya aerosol (misalnya resusitasi jantung paru, pemeriksaan gigi seperti penggunaan scaler ultrasonik dan high speed air driven, pemeriksaan hidung dan tenggorokan, pemakaian nebulizer dan pengambilan swab) dimana dapat memicu terjadinya risiko penularan melalui airborne. (Khairiyah, 2020)

Kasus pertama positif COVID-19 terdeteksi di Indonesia pada awal Maret 2020. Tercatat angka Covid-19 pada tanggal 2 Maret 2021 di dunia sebanyak 115.076.963 kasus dengan jumlah kematian sebesar 2.552.234 jiwa. Di Indonesia pun sampai saat ini terinfeksi 1.347.026 jiwa. Dengan jumlah kematian 36.518 jiwa (Indonesia, 2020). Selanjutnya, dengan memperhatikan eskalasi kasus dan perluasan wilayah terdampak, Pemerintah menerbitkan Peraturan Pemerintah Nomor 21 Tahun 2020 tentang Pembatasan Sosial Berskala Besar (PSBB) Dalam Rangka Percepatan Penanganan COVID-19, serta Keputusan Presiden Nomor 11 Tahun 2020 tentang Penetapan Kedaruratan Kesehatan Masyarakat COVID-19, kemudian diperbaharui dengan Keputusan Presiden Nomor 12 Tahun 2020 tentang Penetapan Bencana Non Alam Penyebaran COVID-19 Sebagai Bencana Nasional.

Beberapa kebijakan yang dilakukan pemerintah terkait penanganan kasus covid 19 antara lain kebijakan berdiam diri di rumah (Stay at Home), kebijakan pembatasan sosial (Social Distancing), kebijakan pembatasan fisik (Physical Distancing), kebijakan penggunaan alat pelindung diri (Masker), kebijakan menjaga kebersihan diri (Cuci Tangan), kebijakan bekerja dan belajar di rumah (Work/Study From Home), kebijakan 
menunda semua kegiatan yang mengumpulkan orang banyak, kebijakan Pembatasan Sosial Berskala Besar (PSBB), dan yang terakhir kebijakan pemberlakuan kebijakan New Normal (Tuwu, 2020).

Kebijakan-kebijakan ini tentunya akan berjalan dengan baik jika ada kerjasama pemerintah dan masyarakat untuk mematuhi kebijakan-kebijakan yang telah dikeluarkan pemerintah. Kebijakan new normal merupakan kebijakan terakhir yang dikeluarkan pemerintah dalam mengatur perilaku masyarakat untuk mencegah penularan covid19(Minggu, 2020). Hal tersebut bukanlah hal yang mudah yang harus dihadapi oleh pemerintah, karena bukanlah mudah dalam mengubah perilaku masyarakat lama menjadi baru. Oleh karena itu, perlunya semangat dalam mengembangkan perilaku yang baru di masyarakat akibat pandemi ini. Salah satu nya yaitu memberikan promosi kesehatan (Notoatmodjo, 2014).

Promosi kesehatan adalah upaya perubahan atau perbaikan perilaku di bidang kesehatan disertai dengan upaya mempengaruhi lingkungan atau hal-hal lain yang sangat berpengaruh terhadap perbaikan perilaku dan kualitas kesehatan (Susilowati, 2016). Promosi kesehatan yang dapat diberikan ke masyarakat tuntuk mencegah penularan covid19 antara lain sering mencuci tangan pakai sabun, menggunakan masker, konsumsi gizi seimbang, perbanyak makan sayur dan buah, hati-hati kontak dengan hewan, rajin olahraga dan istirahat yang cukup, dan bila batuk pilek dan sesak nafas segera ke fasilitas kesehatan.

Berdasarkan data dari hasil survey di Gampong Daboh kecamatan Delima Kabupaten Pidie terdapat 108 KK dengan populasi penduduk berjumlah 351 jiwa, dalam hal penggunaan masker didapatkan hasil bahwa masyarakat yang mematuhi protokol kesehatan masih di bawah 50\%. Kurangnya kesadaran masyarakat untuk menerapkan perilaku social distancing juga masih minim berkisar antara 30\% masyarakat masih suka melakukan kegiatan tanpa menjaga jarak. Oelah karena itu, pengabdian masyarakat ini bertujuan untuk memberikan promosi kesehatan untuk mengedukasi mayarakat akan pentingnya mengikuti protokol kesehatan dalam mencegah penularan kasus covid-19.

\section{BAHAN DAN METODE}

Kegiatan yang dilaksanakan berangsung satu hari yaitu pada tanggal 01 Oktober 2020 mulai pukul 10.00-11.30 WIB di Meunasah Gampong Daboh. Metode yang dilakukan yaitu melakukan promosi kesehatan dengan metode ceramah yang dibantu dengan media laptop, powerpoint, LCD, dan alat pemancar suara. Tahapan-tahapan yang dilakukan antara lain tahapan persiapan yaitu dengan mengurus perizinan dan menetapkan 
Promosi Kesehatan Tentang Corona Virus 2019 di Desa Daboh Kecamatan Delima Kabupaten Pidie

Kartika, Karmila, Fakhryan Rakhman

lokasi dan waktu dilakukannya kegiatan. Tahapan berikutnya adalah tahapan inti acara terdiri atas pembukaan, pelaksaan, dan penutup. Pembukaan adalah sesi kata sambutan dari kepala desa dan pemateri yang menyampaikan tujuan dan maksud dilakukannya kegiatan ini. Tahap pelakanaan yaitu dengan memberikan kuesioner yang telah disiapkan, peserta diberikan waktu 15 menit untuk mengisi, dan tahap berikutnya yaitu menjelaskan materi antara lain pengertian covid-19. penyebab penyakit covid-19, manisfestasi klinis covid-19, dan pencegahan covid-19. Tahap berikutnya adalah penutupan, yaitu melakukan evaluasi dengan cara memberikan kuesioner kembali untuk mengukur pengetahuan dan sikap peserta mengenai pandemi covid-19; berikutnya adalah kegiatan salam penutup. Pengabdian masyarakat ini dihadiri 22 peserta karena diberlakukan jaga jarak dan semua peserta wajib melakukan prokes dengan menggunakan masker dan wajib cuci tangan di awal dan akhir pertemuan. Masyarakat yang hadir adalah para ibu rumah tangga Meunasah Gampong Daboh.

\section{HASIL DAN PEMBAHASAN}

Berdasarkan observasi lapangan yang dirasakan adanya antusias para peserta mengikuti kegiatan ini, karena kasus covid-19 sangat mempengaruhi perubahan hidup di masyarakat Indonsia yang senang bercengkrama satu sama lain, tetapi akibat pandemi ini membuat kegiatan masyarakat terbatas. Berikut adalah gambaran karakteristik peserta yang mengikutu kegiatan pengabdian masyarakat dapat dilihat pada Tabel 1.

\begin{tabular}{|c|c|c|}
\hline Karakteristik & $\mathbf{n}$ & $\%$ \\
\hline \multicolumn{3}{|l|}{ Umur Responden } \\
\hline 18-24 tahun & 3 & 13,6 \\
\hline 25-31 tahun & 7 & 31,8 \\
\hline 32-38 tahun & 5 & 22,7 \\
\hline $39-45$ tahun & 7 & 31,8 \\
\hline \multicolumn{3}{|c|}{ Status Perkawinan } \\
\hline Menikah & 22 & 100.0 \\
\hline Belum Menikah & 0 & 0,0 \\
\hline \multicolumn{3}{|l|}{ Pendidikan } \\
\hline SMP & 4 & 18,2 \\
\hline SMA/SMK & 13 & 59,1 \\
\hline Perguruan Tinggi & 5 & 22,7 \\
\hline Jumlah & 22 & 100.0 \\
\hline
\end{tabular}

Berdasarkan Tabel 1 di atas dapat diketahui bahwa mayoritas peserta berusia 25-31 tahun dan 39-45 tahun masing-masing sebanyak 7 orang $(31,8 \%)$. Semua peserta telah 
menikah yaitu sebanyak 22 orang (100\%), dan berdasarkan pendidikan mayoritas tamat SMA/SMK sebanyak 13 orang $(59,1 \%)$.

Evaluasi pengetahuan dan sikap pseserta mengenai covid-19 berikut dengan pencegahannya sebelum dan sesudah diberikan promosi kesehatan adalah sebagaimana terlihat pada Tabel 1 .

Tabel 2. Distribusi Frekuensi Pengetahuan dan Sikap Peserta Sebelum dan Sesudah Promosi Kesehatan

\begin{tabular}{lrrrrrrrr}
\hline \multirow{2}{*}{ Promosi } & \multicolumn{3}{c}{ Pengetahuan } & \multicolumn{4}{c}{ Sikap } \\
\cline { 2 - 9 } Kesehatan & \multicolumn{2}{c}{ Baik } & \multicolumn{2}{c}{ Kurang } & \multicolumn{2}{c}{ Positif } & \multicolumn{2}{c}{ Negatif } \\
\cline { 2 - 10 } & $\mathrm{n}$ & $\%$ & $\mathrm{n}$ & $\%$ & $\mathrm{n}$ & $\%$ & $\mathrm{n}$ & $\%$ \\
\hline Sebelum & 0 & 0,0 & 22 & 100,0 & 10 & 45,5 & 12 & 54,5 \\
Sesudah & 15 & 68,2 & 7 & 31,8 & 17 & 77,3 & 5 & 22,7 \\
\hline
\end{tabular}

Hasil evaluasi pengetahuan dan sikap sebelum dan sesudah promosi kesehatan menunjukkan bahwa ada peningkatan pengetahuan peserta pada kategori baik yang sebelumnya tidak ditemukan meningkat menjadi 15 orang $(68,2 \%)$ yang pengetahuannya dalam kategori baik dan pada evaluasi sikap didapatkan peningkatan sikap positif dimana sebelum promosi kesehatan hanya sebanyak 10 orang (45,5\%) meningkat menjadi 17 orang $(77,3 \%)$.

Promosi kesehatan pada prinsipnya merupakan upaya dalam meningkatkan kemampuan masyarakat melalui pembelajaran dari, oleh, untuk, dan bersama masyarakat, agar mereka dapat menolong diri sendiri, serta kegiatan yang sumber daya masyarakat, sesuai dengan kondisi sosial budaya setempat dan didukung kebijakan kebijakan publik yang berwawasan kesehatan. Promosi kesehatan hal yang penting dalam memberikan pengertian kepada masyarakat tidak terkecuali dalam kasus pandemi yang sedang dialami oleh dunia, apalagi keberagaman masyarakat yang ada di Indonesia terkadang sering terjadi kesimpangsiuran informasi. Oleh karena itu, bagi petugas kesehatan juga sangatlah penting ikut serta menyampaikan informasi yang akurat dan benar kepada masyarakat agar fokus utama tidak hanya kepada penderita, tetapi juga sangat penting menyebarkan informasi kesehatan agar masyarakat mengikuti protokol kesehatan untuk menurunkan kasus covid-19.

Pengetahuan masyarakat di Desa Meunasah Gampong tentang covid-19 sangatlah minim terlihat dari hasil pemberian kuesioner, dimana tidak ada peserta yang pengetahuannya dalam kategori baik. Perilaku pencegahan covid-19 yang diatur oleh negara dengan berbagai kebijakan tidak akan membuat masyarakat akan sadar pentingnya perilaku pencegahan virus ini karena tidak adanya pengetahuan dasar masyarakat 
Promosi Kesehatan Tentang Corona Virus 2019 di Desa Daboh Kecamatan Delima Kabupaten Pidie

Kartika, Karmila, Fakhryan Rakhman

mengenai virus yang sedang melanda dunia. Bagi masyarakat awan seperti masyarakat di Desa Meunasah, peraturan yang ditetapkan pemerintah hanya memperulit kehidupan mereka karena banyak yang terdampak akibat peraturan pemerintah yang melakukan pembatasan sosial besar-besaran. Peningkatan pengetahuan ini diharapkan agar masyarakat secara sadar tanpa paksaan mengikuti protokol kesehatan dalam mencegah penularan dan peningkatan kasus covid 19. Pembentukan sikap yang positif terhadap keadaan pandemi saat ini, juga akan membantu masyarakat untuk sadar dan taat dalam berperilaku mengikuti protokol kesehatan. Diharapkan dengan pengetahuan yang baik dan sikap yang positif masyarakat dapat taat dan menciptakan suasana yang aman untuk mencegah penularan covid-19. Sikap yang tidak panik berlebihan juga perlu diciptakan agar daya tahan tubuh tetap terjaga, karena salah satu cara mencegah penularan covid-19 yaitu dengan tetap menjaga daya tahan tubuh.

Pada saat materi disampaikan, para peserta aktif bertanya tentang isu-isu yang terkait dengan covid-19 yang terkadang kebenarannya belum terjamin, itulah fungsi besar seorang petugas kesehatan meluruskan isu-isu yang bengkok sehingga masyarakat tidak curiga kepada pemerintah mengenai isu-isu yang beredar dimana belum tentu nilai kebenarannya. Promosi kesehatan ini tidak hanya perlu dilakukan oleh petugas kesehatan tetapi semua juga membutuhkan peran aktif berbagai partai politik termasuk pejabat kesehatan, tokoh masyarakat, tokoh agama, jaringan masyarakat sipil, aparat keamanan daerah, dan organisasi masyarakat. Jika semua anggota masyarakat selalu aktif dan melaksanakan tata cara mematuhi protokol kesehatan di wilayahnya, masyarakat akan lebih mematuhi protokol kesehatan (Yuningsih, 2020).

Dengan kegiatan promosi kesehatan di Desa Meunasah Gampong untuk meningkatkan pengetahuan masyarakat dalam upaya pencegahan covid-19 merupakan bagian yang sangat penting dan bahkan dapat dikatakan sebagai ujung tombak untuk promosi kesehatan di masyarakat desa Meunasah Gampong untuk meningkatkan kesadaran masyarakat untuk berperilaku sesuai dengan protokol kesehatan yang diberlakukan oleh pemerintah dalam menghadapi situasi pandemi.

\section{KESIMPULAN DAN SARAN}

Kesimpulan dalam kegiatan ini adalah adanya peningkatan pengetahuan dan sikap peserta tentang covid-19 sehingga masyarakat di masyarakat desa Meunasah Gampong meningkatkan kesadaran untuk berperilaku sesuai dengan protokol kesehatan. Diharapkan kepada peserta dapat berperan serta dalam menyebarluaskan informasi yang diperoleh dari 
kegiatan ini dan turut aktif dalam kebijakan pemerintah untuk menurunkan angak kesakitan covid-19.

\section{UCAPAN TERIMAKSIH}

Ucapan terima kasih disampaikan kepada masyarakat desa Meunasah Gampong beserta perangkat desa yang telah memberikan kesempatan untuk melaksanakan kegiatan ini dan kepada Institusi pendidikan yang ikut serta mendukung kegiatan ini.

\section{DAFTAR PUSTAKA}

DJASRI, H. (2020). Corona virus dan manajemen mutu pelayanan klinis di rumah sakit. The Lancet, 342(8883), 1317-1322..

Indonesia, R. (2020). Peraturan Menteri Kesehatan Republik Indonesia Nomor 9 Tahun 2020 Tentang Pedoman Pembatasan Sosial Berskala Besar Dalam Rangka Percepatan Penanganan Corona Virus Disease 2019 (Covid-19). Jakarta: Kemeterian Kesehatan Republik Indonesia.

Kemenkes, R. (2020). Pedoman Kesiapsiagaan Menghadapi Corona Virus Diease (Covid19). Jakarta: Kemenkes RI.

Khairiyah, R. (2020). Upaya Pemberdayaan Masyarakat Dalam Pencegahan Dan Pengendalian Covid-19 Dengan "Gotongroyong Jaga Tetangga" Di Rw Viii Kecamatan Jatiasih. Jurnal Antara Abdimas Kebidanan. JURNAL ANTARA ABDIMAS KEBIDANAN, 3(2), 62-67.

Minggu, P. (2020). New Normal; Siapkah Desa Di Kawasan Perbatasan? Jurnal Politicon, $9(2), 17-24$.

Notoatmodjo, S. (2014). Ilmu Perilaku Kesehatan, Cetakan ke-2, Rineka Cipta. GEN, Jakarta.

Susilowati, D. (2016). Promosi kesehatan. Jakarta: PPSDM Kementerian Kesehatan RI.

Tuwu, D. (2020). Kebijakan Pemerintah dalam Penanganan Pandemi COVID-19. Journal Publicuho, 3(2), 267-278. 